\title{
Evaluation of Housing Quality in a Selected Urban Fringe of Ilorin, Kwara State, Nigeria
}

\author{
Ayodeji Ajayi ${ }^{a^{*}}$, Aderonke Ajayi ${ }^{\mathrm{b}}$ \\ ${ }^{a}$ Department of Urban and Regional Planning, Osun State University, Osogbo, Osun State, Nigeria \\ ${ }^{b}$ Department of Architecture, Obafemi Awolowo University, Ile-Ife, Osun State, Nigeria \\ *Corresponding author: ayodeji.ajayi@uniosun.edu.ng
}

Article history: Received: 30 June 2021 Received in revised form: 15 August 2021 Accepted: 16 August 2021 Published online: 31 August 2021

\begin{abstract}
Globally, a lot of research efforts have been put into investigating housing quality in urban areas, but little is known about housing situation in the urban fringes of developing nations. This article examines the factors influencing residents' satisfaction with housing quality in Oke-Andi, an urban fringe in Kwara State, Nigeria. The research design for this study was quantitative in nature. Sampling was carried out at different stages during the field exercise. A preliminary survey of Oke-Andi in Ilorin through satellite imageries and reconnaissance revealed an approximate population of 593 buildings. From this, a $20 \%$ sample size, approximated to 120 buildings were randomly sampled and considered reasonable for the study. Using the housing quality criteria drawn from previous contextual studies, validated and pretested structured questionnaires were used to elicit data on respondents' satisfaction with their dwelling unit, building unit, and neighbourhood quality. Information on residents' socio-economic characteristics was also collected. From each selected building, a copy of the questionnaire was administered on the household heads or adult representatives. At the end of the survey, 120 questionnaires were administered, but only 100 were subsequently retrieved for data analysis. Simple frequency tables and Principal Component Analysis were used for the analysis of collected data. The result of PCA shows neighbourhood attributes, public utilities and building conditions as the factors influencing residents' satisfaction with housing quality. The study recommends community driven urban renewal schemes for redevelopment, rehabilitation and upgrading of the quality of urban fringes.
\end{abstract}

Keywords: Residents' satisfaction, neighbourhood characteristics, urbanization, housing quality, urban fringe.

(C) 2021 Penerbit UTM Press. All rights reserved

\subsection{INTRODUCTION}

Housing studies is an integral part of urban and regional planning, and has stimulated the interest of many researchers in the built environment. Housing is often considered as a multi-functional element; basic human need (Yoade et al.,2018), which often reflects the personality status of the owner when is it reduced to individual unit (Owoeye and Ogundiran,2014). For most people, a house represents the largest investment of their life (Brkanić, 2017). As asserted by Agbola (1998), a house is something much more than an envelope offering protection from elements of weather it includes facilities, amenities and utilities which support community interaction or cohesion, economic prosperity, physical and sound mental health.

Consequently, housing quality studies are justifiable due to importance of housing to human existence. Evidence from literature shows that the quality of housing environment has significant impacts on the health and well-being of residents (Akande,2021; Yaya et al., 2019), their standard of living and productivity as well as environment sustainability (Babalola et al.,2019). Therefore, the quality of housing might influence the total wellbeing of residents physiologically and emotionally. However,despite the importance of qualitative housing to human existence, the problem of deficiency in housing quality in developing economies like Nigeria is common both in urban and rural areas. A study by Agbola(1998) summarised the housing problems in Nigeria, sadly a little has significantly changed in the country. This is because acute housing deficit, overcrowding, unhygienic living conditions, and rising number of homeless people still persists in Nigerian cities and its urban fringes.

The situation is very severe in urban areas due to the fact that most people live in houses that are poor in terms of quality with unsatisfactory environments (Morenikeji et al.,2017). Urbanization and population growth are continually on the increase in Nigeria and globally, thus an unceasing demand for decent housing and liveable environment is implied. The major contributing factors to the growing incidence of poor housing are urbanization and population growth resulting in overstretched physical housing components (Thomas and Hassan2018). The geometric upsurge in the rate of urbanisation worldwide is reflective in the increasing pressure on all facets of the city's fabric: transportation networks, housing provision, employment, social amenities, facilities and sustainable environments are usually overstretched in urban centres. 
According to Fakunle et al., (2018), many urban residents in Nigeria live in very poor and unsatisfactory housing environment. Severe housing deficits result in overcrowded neighbourhoods which is unsurprising since housing is essential to human survival. Similarly, urban fringes are usually offshoots of urbanisation in cites, exhibiting features of both rural and urban spaces, and usually located in areas beyond the edge of services and amenities provided in urban centres. Naturally, growth of cities stimulates the expansion of the peri-urban area; however, if urban fringes are left to grow without planning, the opportunities to make them livable and habitable might be lost.

The quality of housing is dependent on the perceptions or values that residents place on it. For example, Afon, (2006) opines that the socio-economic and cultural values of a society can be seen in the house typology of the townscape. This is because people determine how to design, construct and use the buildings in their environments. It is a projection of the cultural, social and economic values in a community and it can also assist in documenting the surge of historic sequence of events (Olatubara,2007). Corroborating this viewpoint, Adedire and Adegbile (2018), submits that housing quality is extensively controlled by the socio-economic and socio-cultural characteristics of the residents; these determine the level of the quality of housing they can access through their choice of building construction materials and methods of construction. The study by Adedire and Adegbile (2018) asserts further that the influx of lowincome urban immigrants into Lagos peri-urban settlements is significantly impacting on housing quality. Lower income groups inhabit poor residential areas in peri-urban settlements associated with poor physical conditions, illegal development, limited or no access to water, and poor sanitation (Adedire and Adegbile,2018).

Meanwhile, despite the substantial evidence on the factors to consider when assessing quality of housing, there are many contradictions as a results of researchers' divergent views on what criteria to use for measuring housing quality, which is rooted in the multidimensional nature of housing. Evidence from studies assert that the spatial organization and strength of housing units alone do not guarantee satisfaction to housing occupant (Amole.2009; Adedire,2017). This shows other factors have to be considered in selecting the criteria. There are three contexts in which housing quality can be seen; neighbourhood, location and structural quality (Babalola et al,2019; Brkanić, 2017; Adriaanse,2007). Users or resident's satisfaction is also a major component of housing quality evaluation. The significance of residents' perception or satisfaction is stated in a study by Bankole and Oke (2016) which submits that housing quality comprises the characteristics, standards and conditions of residential environment that an individual feels comfortable and satisfied with, suggesting that there is a link between housing quality and residential satisfaction.

Although some studies on housing quality have been done in Nigeria, (Akande,2021; Thomas and Hassan,2018; Babalola et al.,2018; Yoade et al,2018), most of them were conducted in urban settings. In addition, majority of these studies have focused on core and intermediate areas whereas, these emerging urban neighbourhoods (fringes) have not been sufficiently studied. In view of the foregoing, the key research question this study sought to address is: what is the quality of housing and its predictors in Ilorin urban-fringes? This assessment is significant in order to understand to what extent neighbourhood quality, location quality and the use of building materials contribute to the level of housing quality in these settlements. The generated data from this study would be useful to architects, planners and relevant policy makers in attaining livable built environment.

\subsection{LITERATURE REVIEW}

Lifting citizens out of poverty and improving the quality of housing and neighbourhoods are top priority to governments worldwide. Policy makers, administrators and built environment professional are preoccupied with how this goal can be achieved. The generic concept of housing is surrounded by misconceptions; therefore, it may be difficult for other housing attributes to have a universal definition. For instance, (Olayiwola et al. 2006; Sengupta and Tipple 2007; Babalola et al,2019) corroborated this assertion and affirmed the complexity and variances in the definitions and conceptions of housing quality. Moreover, Sinha et al. (2017) opined that housing quality has been addressed by various stakeholders at different levels, and thus, there are different perspectives on its meaning, measurability and possible applications. Nonetheless, issues of housing quality assessment criteria could be broadly divided into four main categories: apartment unit quality assessment criteria; apartment building assessment criteria; neighbourhood quality assessment criteria, and social and economic criteria (Brkanić, 2017). Evaluation of residential and housing quality using residents' satisfaction has been described as the best method of measuring or assessing the housing quality. This approach bridges the gap between theories in housing studies from the residents' perspective for policy makers to provide solutions. This is because the quality of an urban environment is defined by demographic characteristics of the residents, social networks and physical landscapes (Moreno et al.,2014; Bankole and Oke 2016).

In a summary presented in Brkanić (2017) dwelling unit quality criteria are related to the dwelling units' internal spatial organization, design and atmosphere and consist of the following: general unit characteristics, dwelling unit area, design and construction of dwelling units and dwelling units' atmosphere and comfort. In addition, building quality is related to an apartment building's interior and structure, as well as its immediate outdoor environment (Brkanić (2017). Characteristics such as general building characteristics, structural methods and integrity, building's immediate surroundings, and building utilities. The dynamic relationship that exists between the physical features of housing, streets, open spaces and general settings in the neighbourhood determines neighbourhood quality (Adedire and Adegbile,2018). As stated by Clark \& Huang, (2003) cited in Adedire and Adegbile (2018), neighbourhood quality is defined by the effects that neighbourhood characteristics have on a residence as a result of the environment in which it is located. Similar parameters are used to describe neighbourhood quality assessment criteria in Brkanić (2017). They include: general neighbourhood characteristics, traffic criteria, dangers or hazards within and around residential building, and the presence of services and facilities such as shops, restaurants, schools, medical centres, recreational and sporting facilities, police stations and others.

Social factors have also been found to affect satisfaction among housing residents (Babalola et al., 2019; Jiboye,2009). The quality of housing in any area is a function of the socioeconomic composition of the residents. Research abounds on the strength of personal characteristics, for instance, Ibem and Amole (2013) opined that age is one of most vital predictors that determine the quality of housing of an individual. Meanwhile, residents' income was reported as the significant predictor of housing quality (Apansila 2016). Another study by Ibem (2012) found that, income, age, tenure status of dwellers and their educational attainment were part of the principal factors that influenced residents' evaluation of housing quality. Carp and Carp(1982) affirmed the influence of age and gender on housing satisfaction. The study found a significant positive relationship between variables examined. It was reported that with increasing age of respondents, the 
neighbourhood evaluations became increasingly positive. The study reported further that women were less dissatisfied with noise from neighbours' home, less positive about safety and less satisfied with their privacy.

From the evidence provided in literature, it is clear that housing quality can be used to measure the degree of appropriateness of any residential environment for human habitation. Environmental advocates posit that it is best to understand the perceptions of the public in improving the quality of the environment. Afon,(2006) corroborated this view by asserting that working with residents perception data reflets the residents level of concerns, leads to more enlightened decisions, and can guide in designing the focus of development control activities in any given area. Research findings indicate that numerous efforts have been geared towards understanding the factors influencing residential housing quality, hence there are many findings in this regard.

For example, (Gilderbloom et al, 2005) indicated satisfaction to be as a result of the perceived quality of neighbourhood conditions and features of the dwelling unit (housing attributes). Likewise, evidence from literature also indicates that the learned have higher housing expectations and are thus more critical of their housing conditions (Vera-Toscano and Aleca-Amestoy, 2007). Furthermore, women tend to be more satisfied than their male counterparts, while older residents often express greater residential satisfaction than those in younger age groups ( Gilderbloom et al, 2005). Having reviewed the relevant literature on the criteria used for the evaluation of housing quality in existing studies; it becomes evident that user satisfaction is the most important measure of housing quality. It is therefore not surprising that most of the existing studies adopt household survey in housing quality assessment in Nigeria, although there is a dearth of empirical studies on the predictors of housing quality in settlements around the fringes of urban areas.

\subsection{METHODOLOGY}

This current study set out to evaluate housing quality in Oke-Andi, a fringe settlement outside Ilorin city. A cross-sectional survey research design in conjunction with both quantitative and qualitative methods was adopted to measure housing quality. The population under study consisted of all the buildings in Oke-Andi community. A preliminary survey of Oke-Andi in Ilorin through satellite imageries and reconnaissance revealed an approximate population of 593 buildings. From this, $20 \%$ sample size, approximated to 120 buildings were randomly sampled. Using the housing quality criteria drawn from previous contextual studies (Adewale et al. 2018; Adedire and Adegbile,2018; Bankole and Oke 2016), validated and pretested structured questionnaires were used to elicit data on respondents' satisfaction with their dwelling unit, building unit, and neighbourhood quality. Information on residents' socio-economic characteristics was also collected. From each selected building, a copy of the questionnaire was administered on the household heads or adult representatives. At the end of the survey, 120 questionnaires were administered, but only 100 were subsequently retrieved for data analysis. Residents' satisfaction was assessed by asking the respondents to provide rating on the same 5-point Likert-type scale ranging from ' 1 ' for Very Dissatisfied to ' 5 ' for Very Satisfied. Descriptive analysis was used to analyse data on dwelling unit, building unit neighbourhood quality. Each response was multiplied by the number of respondents, to obtain the weighted value (WV). The summation of the weighted value $\left(\sum \mathrm{WV}\right)$ was divided by the number of respondents $(\mathrm{n})$ to obtain each component mean weighted value (MWV). The mean of the weighted value (MWV) was then obtained by dividing the summation of mean weighted value ( $\left.\sum \mathrm{MWV}\right)$ by total number of infrastructure/ variables (y) surveyed in the study. Following the approach used in Satake, (2016), frequencies and percentages of the number of responses were reduced to a mean score from which the assessments of housing quality variables could be easily determined. Principal Component Analysis (PCA) was used to predict factors influencing residents' satisfaction with housing quality.

\section{Limitation(s) of the study}

It is important to note that the scope of this study was limited to just one fringe settlement in Ilorin metropolis; hence, the findings may not be generalizable for the entire city. In addition, not all the housing quality indicators identified in literature were used in this study as such, findings are limited to the indicators investigated in the study.

\subsection{The Study Area}

Ilorin town is located in the north central zone of Nigeria with a longitude of $4^{\circ} 35^{\prime} \mathrm{E}$ and latitude of $8^{\circ} 3^{\prime} \mathrm{N}$, co-ordinates: $8^{\circ} 30^{\prime} \mathrm{N}, 4^{\circ} 33^{\prime}$ E(Adiama,2018). It is about $302 \mathrm{~km}$ north of Lagos, $602 \mathrm{~km}$ south of Kaduna and about $475 \mathrm{~km}$ south of Abuja, the federal capital territory of Nigeria; it serves as a major stop station from the northern part of the country to the southern part of the country (see Figure 1). Its population, very largely Yoruba, include powerful Fulani and Hausa minorities. Before the early nineteenth century, Ilorin appears to have been a small town, on the eastern rim of the Oyo Empire, apparently with the Igbomina to the east and the Nupe to the northeast. Oke-Andi like most other communities in fringes of the ancient city has its locales relying majorly on agricultural activities. It is gradually becoming an urban centre with the influence of urban expansion from the core to the peripheral areas of Kwara State of Nigeria (2008). 


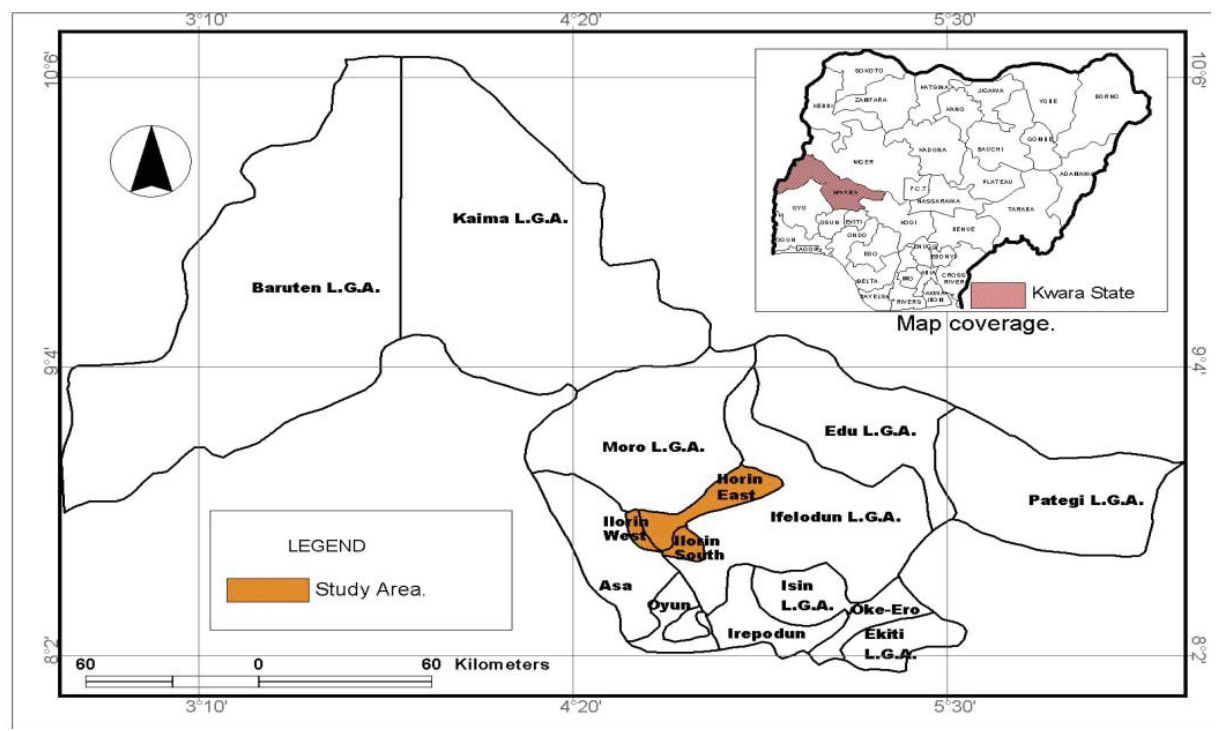

Figure 1 Maps of Nigeria, Kwara State and the Study Area Source: Authors' Fieldwork

\subsection{RESULTS}

This study was conducted to identify the perception of human resources, namely teachers on the level of implementation of learning. The distribution of respondents by their demographic attributes are shown in Table 1. The respondents' gender, marital status, age, educational attainment, occupation, and average monthly earnings were the six (6) personal information requested in the study.

The distribution of respondents by gender shows that $45 \%$ were male and $56 \%$ were female. This infers that both genders were fairly represented but female were more dominant among the respondents. The slight variation in gender representation might be explained by data having been collected on workdays during working hours. More often than not, most male household members would be at their workplaces which are not home-based. Information arising from the survey also shows that about $40 \%$ of the total respondents were between $46-55$ years, this age group was in the majority. It also became evident that $25 \%$ of the respondents were $56-65$ years, while those who were $26-35$ years constituted $21 \%$. Only $1 \%$ of the total respondents was above 66 years while those who were below 25 years made up $13 \%$ of the study population.

Table 1 Socio-demographic background of the respondents.

\begin{tabular}{lll}
\hline Age & Frequency & Percentage \\
\hline Less than 24 & 13 & 13.0 \\
$26-35$ & 21 & 21.1 \\
$46-55$ & 40 & 40.0 \\
$56-65$ & 25 & 25.0 \\
66 and Above & 1 & 1.0 \\
Total & 100 & 100 \\
Gender & & \\
Male & 45 & 45 \\
Female & 55 & 55 \\
Total & 100 & 100.0 \\
Marital status & & \\
Single & 13 & 13.0 \\
Married & 84 & 84.0 \\
Separated & 3 & 3.0 \\
Total & 100 & 100 \\
Level of education & & \\
No formal education & 7 & 7.0 \\
Primary & 5 & 5.0 \\
Secondary/school certificate & 13 & 13.0 \\
College/vocational/polytechnic & 20 & 20.0 \\
University & 55 & 55.0 \\
Total & 100 & 100 \\
Occupation & & \\
\hline & & \\
& &
\end{tabular}




\begin{tabular}{lll}
\hline Trading & 5 & 5.0 \\
Civil servant & 75 & 75.0 \\
Artisan & 5 & 5.0 \\
Professional & 4 & 4.0 \\
Student & 11 & 11.0 \\
Total & 100 & 100 \\
Average Monthly Earnings & & \\
Less than $\$ 10,000$ & 11 & 11.0 \\
$\mathrm{~N} 10,000-\mathrm{N} 20,000$ & 8 & 8.0 \\
$\mathrm{~N} 20,000-\mathrm{N} 30,000$ & 7 & 7.0 \\
$\mathrm{~N} 30,000-\mathrm{N} 40,000$ & 8 & 8.0 \\
$\mathrm{~N} 40,000-\mathrm{N} 50,000$ & 12 & 12.0 \\
Above $\mathrm{N} 50,000$ & 54 & 54.0 \\
Total & 100 & 100 \\
\hline
\end{tabular}

The study population consisted of more married people (84\%) whereas $13 \%$ were single and only $3 \%$ were separated or divorced. The high concentration of married people might be explained by the predominant religious, cultural beliefs and practices in the locality. The literacy level of the population was somewhat high; approximately half of the respondents $(55 \%)$ had up to the university education. About $33 \%$ had secondary and post-secondary education while just 7\%were uneducated. The distribution of respondents based on average monthly income revealed that most of the residents live below poverty line, regardless of their high literacy level; $11.0 \%$ of the respondents earned less than \#10,000 monthly, 8.0\% earned between \#10,000-\#20,000 monthly, 7.0\% earned between \#20,000-\#30,000 monthly, 8.0\% earned between \#30,000-\#40,000 monthly, $12.0 \%$ earned between \#40,000-\#50,000 monthly while 54.0\% earned above \#50,000 monthly. In terms of employment status, three quarters (75\%) of population were civil servants, those employed in the private sector (14\%) and $11 \%$ were students.

\subsection{Residents' Evaluation Of Housing Quality}

Table 2 shows the variables that were used to evaluate residents' satisfaction with housing quality in the study area. From the results presented in Table 2, it is evident that out of all the indices of housing quality examined, respondents were mostly satisfied with building elements (roof, wall, floor, doors, windows and painting), the mean values of these attributes ranged from 3.8 to 4.1. Meanwhile most of the respondents were dissatisfied with attributes relating to ambience (ventilation, lighting, and condition of ceiling), and neighbourhood facilities.

Table 2 Respondents' assessment of housing quality

\begin{tabular}{|c|c|c|c|c|c|c|c|c|c|}
\hline & Housing Attributes & $\begin{array}{l}\text { Frequency } \\
\text { (N) }\end{array}$ & $\operatorname{VS}(5)$ & JS(4) & $\mathbf{S}(3)$ & $\mathbf{D}(2)$ & VD(1) & SMV & MWV \\
\hline 1 & Roof & 97 & 230 & 88 & 87 & --- & ----- & 405 & 4.1 \\
\hline 3 & Floor & 95 & 130 & 152 & 87 & 4 & & 373 & 3.9 \\
\hline 4 & Door & 90 & 180 & 64 & 102 & 8 & & 354 & 3.9 \\
\hline 7 & Staircase & 58 & 90 & 56 & 48 & 20 & & 214 & 3.6 \\
\hline 8 & Toilet & 92 & 10 & 40 & 84 & 36 & 34 & 204 & 2.2 \\
\hline 9 & Bathroom & 93 & & 44 & 84 & 60 & 24 & 212 & 2.2 \\
\hline 10 & Ceiling & 89 & $\overline{5}$ & 28 & 111 & 44 & 22 & 210 & 2.3 \\
\hline 11 & Ventilation & 97 & & 32 & 69 & 30 & 51 & 182 & 1.8 \\
\hline 16 & Parking Lots & 88 & $\overline{165}$ & 44 & 117 & 8 & 1 & 335 & 3.8 \\
\hline 17 & Overall Housing Unit. & 80 & 45 & 60 & 80 & 24 & 4 & 210 & 2.6 \\
\hline 18 & Overall Housing Environment & 82 & 40 & 40 & 144 & 26 & 3 & 253 & 3.0 \\
\hline 19 & Security & 88 & 165 & 52 & 108 & 6 & 3 & 334 & 3.7 \\
\hline 20 & Public Health & 85 & 30 & 96 & 66 & 52 & 7 & 251 & 2.9 \\
\hline 21 & Public Primary School & 78 & 30 & 24 & 111 & 38 & 10 & 213 & 2.9 \\
\hline 22 & Public Sec. School & 84 & 40 & 48 & 120 & 38 & 5 & 251 & 2.9 \\
\hline 23 & Markets & 85 & 40 & 36 & 144 & 38 & 6 & 264 & 3.1 \\
\hline 24 & Refuse Management & 84 & 25 & 96 & 99 & 38 & 3 & 261 & 3.1 \\
\hline 25 & Roads & 84 & 20 & 24 & 153 & 38 & 4 & 239 & 2.8 \\
\hline 26 & Drainage & 84 & 20 & 32 & 135 & 46 & 4 & 237 & 2.8 \\
\hline
\end{tabular}




\subsection{Factors Influencing Residents' Satisfaction with Housing Quality}

Table 3 presents the result of the analysis to test the appropriateness of information collected for factor analysis; as presented, the KMO is 0.777 which is above the minimum recommended value of 0.600 . The results of the Kaiser-Meyer Okin test show that the data used for this test were adequate, because the variables yielded a significant Bartlett's test $(p<0.000)$. Therefore, the model is assumed to be well suitable for further analysis. Another very important test of the appropriateness of the model was to take note of the size of communalities which represents the strength of the linear association among variables and components. The value of communalities ranges between 0 and 1 with higher observed value representing the fact a greater share of common variance is explained by extracted components. Table 4 shows that the results of the communalities ranged in value from 0.671 to 0.910 which could be considered to fall within an acceptable range. Tables 5 and Table 6 show the results for total variance explanation and rotation obtained from factor analysis to identify factors (components) influencing housing quality in Oke-Andi, Kwara State. Using the Principal Component Analysis with initial Eigen values greater than 1 as the benchmark, the orthogonal varimax rotation and a factor loading of 0.4 were used to determine the number of factors to retain as described in Ola-awo et al.,(2021). Following the initial premise of Eigen value earlier stated, four factors(components) explained approximately $80 \%$ of the observed variance. Component 1 (Building Conditions) was the dominant because it explained almost half of the variation $(47.8 \%$ ), this was followed by Component 2(Neighbourhood Public Utilities) which explained $14 \%$ of the variation after factorization. The third component (Neighbourhood Services) explained approximately 10\% of the while the general housing environment in the fourth component accounted for $7.7 \%$ of the total variance. Results of the relationships between components and variables after rotation are shown in Table 5. It is clear that correlation exist among component 1(Building conditions) and security, residents' living conditions, quality of accommodation spaces, architectural design of buildings, provision of carparks, refuse management, sewerage management and public water supply. In the second component, four variables were loaded and had correlation with Neighbourhood Public Utilities, namely availability of markets, presence of health centres, presence of primary and secondary schools. Quality of roads, drainages, sewerage management, public water supply and refuse management correlated with component 3(Neighbourhood Services). Only two variables (residents' overall satisfaction with housing unit and general housing environment) loaded into the fourth component. The four emerged factors explained about $80 \%$ of the total variance after factorisation of the identified variables in this study. It was revealed that resident's perception of housing was significantly determined by the building conditions, adequacy of neighbourhood services and utilities.

Table $3 \mathrm{KMO}$ and Bartlett's test of residents' perception of housing quality

\begin{tabular}{lll}
\hline Kaiser-Meyer-Olkin measure of sampling adequacy. & 0.777 \\
\hline & Approx. chi-square & 1147.534 \\
$\begin{array}{l}\text { Bartlett's test } \\
\text { of sphericity }\end{array}$ & Df & 136 \\
& Sig. & 0.000 \\
\hline
\end{tabular}

Table 4 Communalities of residents' perception of housing quality

\begin{tabular}{lcl}
\hline & Initial & Extraction \\
\hline Security & 1.000 & 0.770 \\
Living conditions in your dwelling & 1.000 & 0.671 \\
Accommodation space & 1.000 & 0.846 \\
Design of building & 1.000 & 0.865 \\
Car parks/lay-bys & 1.000 & 0.910 \\
Refuse management & 1.000 & 0.751 \\
Roads & 1.000 & 0.795 \\
Drainages & 1.000 & 0.802 \\
Sewage management & 1.000 & 0.830 \\
Public water supply & 1.000 & 0.756 \\
Public health facilities & 1.000 & 0.858 \\
Public primary schools & 1.000 & 0.884 \\
Public secondary school & 1.000 & 0.821 \\
Markets & 1.000 & 0.830 \\
Recreational facilities & 1.000 & 0.566 \\
Overall housing unit & 1.000 & 0.783 \\
Overall housing environment & 1.000 & 0.802 \\
\hline
\end{tabular}

The rotated component matrix of variables that influences residents' perception of housing quality is presented in Table 6 . 
Table 5 Total variance explained of residents' perception of housing quality

\begin{tabular}{|c|c|c|c|c|c|c|c|c|c|}
\hline \multirow[b]{2}{*}{ Component } & \multicolumn{3}{|c|}{ Initial eigenvalues } & \multicolumn{3}{|c|}{ Extraction sums of squared loadings } & \multicolumn{3}{|c|}{ Rotation sums of squared loadings } \\
\hline & Total & $\begin{array}{l}\% \\
\text { Variance }\end{array}$ & $\begin{array}{l}\text { of Cumulative } \\
\%\end{array}$ & Total & $\begin{array}{l}\% \\
\text { Variance }\end{array}$ & $\begin{array}{l}\text { of Cumulative } \\
\% \\
\end{array}$ & Total & $\begin{array}{l}\% \\
\text { Variance }\end{array}$ & $\begin{array}{l}\text { of Cumulative } \\
\%\end{array}$ \\
\hline 1 & 8.142 & 47.896 & 47.896 & 8.142 & 47.896 & 47.896 & 4.951 & 29.123 & 29.123 \\
\hline 2 & 2.392 & 14.071 & 61.967 & 2.392 & 14.071 & 61.967 & 3.427 & 20.161 & 49.284 \\
\hline 3 & 1.693 & 9.957 & 71.924 & 1.693 & 9.957 & 71.924 & 2.937 & 17.279 & 66.563 \\
\hline 4 & 1.312 & 7.718 & 79.642 & 1.312 & 7.718 & 79.642 & 2.223 & 13.079 & 79.642 \\
\hline 5 & 0.820 & 4.824 & 84.466 & & & & & & \\
\hline 6 & 0.493 & 2.902 & 87.368 & & & & & & \\
\hline 7 & 0.467 & 2.746 & 90.114 & & & & & & \\
\hline 8 & 0.426 & 2.508 & 92.622 & & & & & & \\
\hline 9 & 0.248 & 1.458 & 94.080 & & & & & & \\
\hline 10 & 0.233 & 1.370 & 95.451 & & & & & & \\
\hline 11 & 0.220 & 1.294 & 96.745 & & & & & & \\
\hline 12 & 0.139 & 0.817 & 97.562 & & & & & & \\
\hline 13 & 0.120 & 0.708 & 98.269 & & & & & & \\
\hline 14 & 0.106 & 0.623 & 98.893 & & & & & & \\
\hline 15 & 0.083 & 0.488 & 99.381 & & & & & & \\
\hline 16 & 0.077 & 0.453 & 99.833 & & & & & & \\
\hline 17 & 0.028 & 0.167 & 100.000 & & & & & & \\
\hline
\end{tabular}

Table 6 Rotated component matrix of residents' perception of housing quality

\begin{tabular}{|c|c|c|c|c|}
\hline & \multicolumn{4}{|c|}{ Component } \\
\hline & 1 & 2 & 3 & 4 \\
\hline Security & 0.750 & & & \\
\hline $\begin{array}{l}\text { Living conditions in your } \\
\text { dwelling }\end{array}$ & 0.708 & & & \\
\hline Accommodation space & 0.859 & & & \\
\hline Design of building & 0.874 & & & \\
\hline Car parks/lay-bys & 0.937 & & & \\
\hline Refuse management & 0.642 & & 0.548 & \\
\hline Roads & & & 0.837 & \\
\hline Drainages & & & 0.766 & \\
\hline Sewage management & 0.621 & & 0.604 & \\
\hline Public water supply & 0.516 & & 0.539 & \\
\hline Public health facilities & & 0.742 & & \\
\hline Public primary schools & & 0.845 & & \\
\hline Public secondary school & & 0.842 & & \\
\hline Markets & & 0.798 & & \\
\hline Recreational facilities & & & & \\
\hline Overall housing unit & & & & 0.811 \\
\hline Overall housing environment & & & & 0.848 \\
\hline
\end{tabular}

\subsection{DISCUSSION}

The aim of this study was to examine residents' perception of quality of housing and its predictors in urban-fringes of Ilorin. The results on the demographic attributes of the respondents indicate the prevalence of highly literate residents who were majorly low-income earners. The high-incidence of low-income earners in this community might be related to the fact that land procurement is cheaper in Oke-Andi than what is obtainable within Ilorin metropolis. This result was expected since migrants and low-income earners tend to have little purchasing power to live within major cities. Despite the fact that most of the respondents were low-income earners, it was surprising to discover that they were relatively satisfied with some aspects of their buildings. Although some of these buildings were not new, they appeared to have sound structural integrity. Most of the respondents were satisfied with the quality of buildings which were constructed 
with conventional building materials such as cement sandcrete blocks, aluminium burglar-proof windows, mostly wooden panel internal doors, and steel external doors. This result has some implications; firstly, it might show that these construction materials are widely known, readily available, relatively cheap and easy to maintain. This finding similarly corroborates earlier studies on the major types of building materials in Nigerian urban cities (Akinola,1998; Olayiwola et al. 2006; Adedire and Adegbile,2018; Babalola et al,2019). Thus, it is imperative that the relevant government agencies ensure quality and cost control in the production of that these building materials to sustain the quality of housing in the country.

Meanwhile, regardless of the average satisfaction level of the residents with the exterior components of the dwellings, there was grave displeasure with the internal dwelling quality and ambience of their houses. Notably, respondents were dissatisfied with the quality of their ceiling, ventilation, lightning, and the architectural design of their buildings. This finding contradicts Adedire and Adegbile, (2018) reporting good natural ventilation and lighting in most of the buildings in Ibeju-Lekki peri-urban settlement of Lagos Nigeria. One possible explanation for this variation is the locational differences of these settlements. According to Morenikeji et al., (2017) a city like Lagos boasts of a high housing quality because economic and administrative activities are higher unlike other states which have a lower housing quality. The finding underscores the role of income in the social production of houses in Nigeria; more often than not, home owners in urban fringes lack the financial ability to engage the services of relevant professionals in the design of their dwellings. Consequently, dwelling quality in Oke-Andi, Ilorin was affected by household income.

With regard to satisfaction with neighbourhood facilities, services and amenities, it was found that most respondents were not satisfied. This did not come as a surprise due to the level of informality of the settlement. According to the respondents most of the neighbourhood amenities were provided through non-governmental agencies, as well as personal, and communal efforts. Some studies of housing quality in suburban areas of Akure,Ondo State (Omole,2010;Olotuah 2006), found similar results. One might be tempted to think that the quality of neighbourhood facilities in Nigerian city centres will be better due to high government visibility and presence, but the situation is not necessarily so. For example, in a study of residents' perception of quality of public housing in Lagos, Nigeria, low level of satisfaction was reported (Babalola et al., 2019,2016). In summary the factors predicting housing quality in the study are level of income, residents' perception of the adequacy of housing characteristics and satisfaction with the level of amenities in the neighbourhood.

\subsection{CONCLUSION}

Housing quality in Oke-Andi, an urban fringe of Ilorin, Kwara State, Nigeria was investigated in this study. Using Principal Component Analysis, the results revealed that neighbourhood features, public utilities and building conditions were the factors influencing residents' satisfaction with housing quality. It is therefore important to give adequate considerations to public utilities and facilities in neighbourhoods during the planning process. Routine maintenance and the use of quality building materials alleviate housing conditions, thereby increasing residents' satisfaction with housing quality. The study recommends that existing blighted conditions should be rehabilitated and redeveloped. Provisional layout plans are important to guide the growth of Oke-Andi community and reduce organic physical developments.

In addition, active citizens involvement is recommended for the redevelopment programme in the community; community participation in developmental projects is highly advocated. To ensure the successful implementation of town planning intervention, locals and government players must collaborate at all stages of the programme. Another important recommendation is the establishment of an effective and efficient development control team. Planning authorities in charge of such community should be encouraged to be more effective in the discharge of their duties, especially in the aspect of checking unplanned and unauthorized development. Future studies on housing quality in urban fringes are encouraged to use more objective quantitative criteria in the assessment of quality. This might possibly reduce the bias of respondents in the evaluation of housing attributes which can be objectively measured. This will give room for comparison and expand current knowledge of the quality of housing in urban fringes.

\section{References}

Adedire, F. M., \& Adegbile, M. (2018). Assessment of housing quality in Ibeju-Lekki peri-urban settlement, Lagos State, Nigeria. Acta Structilia, 25(1), 126-151.

Adedire, F.M. (2017). Differentials in metropolitanisation trends in Lagos suburbia. Journal of Sustainable Development, 10(6), 14-27. https://doi.org/10.5539/jsd.v10n6p14

Adesina, A. (2007). Socio-spatial transformations and the urban fringe landscape in developing countries, United Nation University Institute for Environment and Human Security (UNU-UHS) Summer Academy on Social Vulnerability and Resilience Building in Mega city, Munich, Germany

Adewale, B. A., Babalola, D. O., Jegede, F., Afolabi, A. O., Oyenuga, T., \& Obi, C. (2018). Dataset on cost comparative analysis of different walling materials in residential buildings in a developing economy. Data in Brief, 19(2018), 1918-1924.

Adriaanse, C. (2007). Measuring residential satisfaction: A residential environmental satisfaction scale, Journal of Housing and the Built Environment, 22(3), 287-304.

Afon, A. (2006). The use of residents' satisfaction index in selective rehabilitation of urban core residential areas in Developing Countries, International Review for Environmental Strategies, 6(1), 137-152.

Agbola, T. (1998). The Housing of Nigerians; A Review of policy Development and Implementation. Research Report 14, Development Policy Centre, Ibadan, Nigeria

Akande,O.K(2021). Urbanization, Housing Quality and Health: Towards a Redirection for Housing Provision in Nigeria, Journal of Contemporary Urban Affairs, 5(1), 35-46. https://doi.org/10.25034/

Akinola, S.R. (1998). The pattern of housing quality in Osogbo, Osun State, Nigeria, Ife Journal of Environmental Design and Management, 1\&2, 109-120 Obafemi Awolowo University, Ile-Ife

Aliu, I.R. and Adebayo, A. (2010). Evaluating the influence of housing quality on Urban Residents Well-being: The case study of Lagos Nigeria, International Journal of Academic Research 12 (6), 401-410.

Amole, D. (2009): Residential satisfaction in students' housing, Journal of Environmental Psychology, 29, 76-85, https://doi.org/10.1016/j.jenvp.2008.05.006

Apanisile B.O (2016): Residents' Perception of Government- Supported Solid Waste Management Services in Osun State, Nigeria, Unpublished M.Sc. Thesis, Department of Urban and Regional Planning, ObafemiAwolowo University, Ile Ife, Nigeria.

Babaloa.D.B. Ibem, E.O., Olotouah,A,O. Akunnaya,P.O, Adewale,A,B., Fulani A.O.(2016): Residents' Perception of Quality of Public Housing in Lagos, International Journal of Applied Environmental Sciences 11(2), 583-598. ISSN 0973-6077 
Babaloa.D.B. Ibem, E.O., Olotouah,A,O. Akunnaya,P.O, Adewale,A,B., Fulani A.O.(2019). Housing quality and its predictors in public residential estates in lagos, Nigeria, Environment,Development and Sustainability,2019. doi.org/10.1007/s10668-019-00367-8

Bankole, E. T., \& Oke, O. M. (2016). Efects of housing quality and overcrowding on psychological wellbeing of residents in Lagos State, Nigeria. IOSR Journal of Humanities and Social Science, 21(11), 14-22

Brkanić, I. (2017). Housing quality assessment criteria. Scientifc Paper Available on https://bib.irb.hr/datot eka/921889.42-30-06-2017-10-42-21-paper-5-brkanic.pdf. Retrieved on 28 June 2021.

Carp,F.M. and Carp,A(1982). Perceived environmental quality of neighbourhoods: Development of assessment scales and their relation to age and gender, Journal of Environmetal Pscychology,2,295-312

Clark, W.A.V. \& Huang, Y. (2003). The life course and residential mobility in British housing markets. Environment and Planning A, 35, 323-339. https://doi.org/10.1068/a3542

Comrey, A. LandLee, A.H.B. (1992). A First Course in Factor Analysis, 2nd ed., Hillsdale, New Jersey, Erbaum, 1992.

Fakunle, A., Ogundare, J., Olayinka-Alli, L., Aridegbe, M., Bello, T., Elujulo, O., et al. (2018). Housing quality and risk factors associated with respiratory health conditions in Nigeria. In A. Almusaed \& A. Almssad (Eds.), Housing, 19-20. London: IntechOpen. https://doi.org/10.5772/intechopen.78543.

Ibem, E. O. (2012). Residents' perception of the quality of public housing in urban areas in Ogun State, Nigeria. International Journal of Quality \& Reliability Management, 29(9), 1000-1018

Ibem, E.O. and Amole, D. (2013). Residential Satisfaction in Public Core Housing in Abeokuta, Ogun State, Nigeria. Journal of Social Research Indicators, 113 (1), 563- 581

Jiboye, (2009). The significance of households' characteristics on housing quality in Nigeria, Journal of Geography and Planning Sciences 2, 1-10.

Kwara State of Nigeria, (2008). Kwara at a glance Ministry of Home Affairs Information and Social Development, Government Printer, Ilorin, 26

Mabogunje, A.L. (2010). Shelter Provisions in Developing Countries, The Influence of Standards and Criteria. Chichester, John Wiley and Sons.

Moreno Pires,S.,Fidelis,T\& Ramous,T.B(2014). Measurinnnnng and comparing local sustainsble development through common indicators: Constranits and achievement in practice, Coties 39, 1-9

Morenikeji,W.,Emmanuel,Umaru. , Halilu.P , Solomon,J. , Owoeye,I , and Adeleye, B.M.(2017). Spatial analysis of housing quality in Nigeria. International Journal of Sustainable Built Environment, 6(2), 309-31. http://dx.doi.org/10.1016/

Onibokun, P. (1990). Urban housing in Nigeria, NISER, Ibadan.

Ola-awo, W., Alayande, A., Olarewaju, G. and Oyewobi, L. (2021). Critical success factors for effective internal construction stakeholder management in Nigeria. Acta Structilia, 28(1), 1-31

Olotuah, A. O. (2006). Housing quality in suburban areas: An empirical study of Oba-Ile, Nigeria. Dimensi Teknik Arsitektur, $34(2) .133$ - 137.

Olatubara,C.O.(2007). Housing development and management: a book of readings, edited by Agoola, Egungobi and Olatubara

Olatunde,D,B,Olayiwola, L., Adeleye,. In Paper presented at the CIB W107 construction in developing countries international symposium 18-20 January, Santiago, Chile. Retrieved on 26 Nov 2018 from www.irbnet.de/daten/iconda/CIB1936.pdf.

Omole,K.F.(2010).An Assessment of Housing Condition and Socio-Economic Life Styles of Slum Dwellers in Akure, Nigeria, Contemporary Management Research, $6(4), 273-290$

Owoeye, J.O. and Ogundiran, A.O. (2014). A study on housing and environmental quality of Moniya community in Ibadan, Nigeria, Journal of Environment and Earth Science, 4(13), 51-60.

Oseland, N. A. (1990). An evaluation of space in new homes, Proceedings of the IAPS Conference, 322-331, Ankara

Ukoha,O.and Beamish, J.O. (1997): Assessment of residents' satisfaction with Public Housing in Abuja, Nigeria, Habitatitnl. 21(4), 445-460.

Robin,M,Matheaeu-Police,A,Couty,C.(2007). Development of a scale of perceived environmental annoyances in urban settings, Journal of Environmental Physcology,27, 55-86

Sengupta, U., \& Tipple, A. G. (2007). The performance of public-sector housing in Kolkata, India, in the post reform milieu. Urban Studies, 44(10), $2009-2027$.

Satake, E.B. (2016). Basic statistical tools in research and data analysis. Indian Journal of Anesthesia, 60(9), 662-669. https://doi. org/10.4103/0019-5049.190623

Sinha, R. C., Sarkar, S., \& Mandal, N. R. (2017). An overview of key indicators and evaluation tools for assessing housing quality: A literature review. Journal of Institution of Engineers (India) Series A, 98(3), 337-347. https://doi.org/10.1007/s40030-017-0225-z

Tabachinik, B. and Fidell, L.S. (1996). Using Multivariate Statistics. Harper Coins College Publishers, New York, 3rd ed., 667.

Thomas, O. S. and Hassan, A. O. (2018). Assessment of Factors Influencing Housing Quality in the Coastal Community. International Journal of Innovation and Sustainability, 2: 1-8

Yaya S, Uthman OA, Okonofua F, Bishwajit G, (2019). Decomposing the rural-urban gap in the factors of under five mortality in sub-Saharan Africa? Evidence from 35 countries. BMC Public Health 19:616

Yoade,A., Adeyemi,O and Yoade,O.(2018). Assessment of Housing Quality in Ede, Nigeria, Asian Themes in Social Sciences Research 1(2), 76-83 ISSN: 2578-5516 2018 DOI: 10.33094/journal.139.2018.12.76.83 